\title{
Stressing a tired host: Cryptosporidium species and Helicobacter pylori infections in diabetes mellitus patients with gastrointestinal manifestations
}

Original

Article

\author{
Hanaa 0 Fadl $^{1}$, Naglaa M Elsayed ${ }^{2}$, Mohammed K Rehan ${ }^{3}$, Naglaa S El-Gebaly ${ }^{1}$, \\ Iman R Abdel-Shafi ${ }^{1}$
}

Departments of Medical Parasitology ${ }^{1}$, and Internal Medicine ${ }^{2,3}$, Faculties of Medicine, Cairo $^{1,2}$ and Beni Suef ${ }^{3}$ Universities, Egypt

\begin{abstract}
Background: Cryptosporidium spp. and Helicobacter pylori are widespread gastrointestinal infections that appear to resist treatment in many cases. Cryptosporidiosis results in increased intestinal permeability while H. pylori causes atrophic changes in stomach, and both are opportunistic pathogens. The outcome of infection depends largely on the degree of the host immune status. Diabetes mellitus (DM) is a growing health problem in Egypt, with detrimental consequences that can affect the immune system, the gastrointestinal tract, and virtually all body systems, exposing diabetic patients to higher susceptibility to infections and intensified morbidity.

Objective: The present study was designed to determine the burden of Cryptosporidium spp. and H. pylori among diabetic patients compared to non-diabetic patients attending Kasr Al Ainy hospitals.

Subjects and Methods: Stool samples, demographic and clinical data were collected from 80 patients, 40 diabetics and 40 non-diabetics, with gastrointestinal manifestations. Microscopic stool examination and coproimmunoassays for the detection of Cryptosporidium spp. and H. pylori were performed for all samples.

Results: Cryptosporidium spp. infection was detected in 15\% of diabetics; with a frequency of $7.4 \%$ and $30.8 \%$ in patients with controlled DM and uncontrolled DM, respectively, and in 5\% of non-diabetics. While $H$. pylori was equally detected at a rate of $60 \%$ in non-diabetic and diabetic patients $(51.9 \%$ and $76.9 \%$ in patients with controlled DM and uncontrolled DM, respectively). Microscopic examination of stools revealed Blastocystis in 25\% of diabetics $22.2 \%$ in controlled DM versus $30.7 \%$ in uncontrolled DM) and in 5\% of non-diabetic patients. Co-infection with Cryptosporidium and H. pylori occurred in 10\% of diabetic cases (3.7\% in controlled DM versus $23.1 \%$ in uncontrolled DM), and in $5 \%$ of non-diabetic patients.

Conclusion: Diabetic patients had a higher infection rate of Cryptosporidium as well as Blastocystis in comparison to non-diabetics. Screening for intestinal parasites is needed to control the infection and reduce morbidity in diabetics.
\end{abstract}

Keywords: Blastocystis; coproimmunoassays; Cryptosporidium; diabetics; gastrointestinal manifestations; H. pylori.

Received: 24 August, 2021, Accepted: 19 October, 2021.

Corresponding Author: Iman R. Abdel-Shafi, Tel.: +20 1223331861, E-mail: irriad@kasralainy.edu.eg

Print ISSN: 1687-7942, Online ISSN: 2090-2646, Vol. 14, No. 3, December, 2021.

\section{INTRODUCTION}

No doubt, DM is a major health issue, with around 451 million individuals affected worldwide ${ }^{[1]}$. In Egypt, the number of diabetic patients has alarmingly increased over the past decade, placing it among the top 10 countries with highest prevalence of $\mathrm{DM}^{[2]}$. According to the American Diabetes Association, a controlled glycemic state is achieved at a glycated hemoglobin (HbA1c) level of $<7 \%$, while higher levels $(>7 \%)$ are considered uncontrolled DM with high risk of complications ${ }^{[3]}$.

Uncontrolled DM tends to escalate the risk of other diseases by inducing macrovascular and microvascular damage ${ }^{[4]}$. Moreover, the impaired immune system together with metabolic imbalance intensify the susceptibility to several pathogens ${ }^{[5]}$.
Infections in diabetic patients increase the disease burden by the related comorbidities, in addition to the economic burden caused by the cost of care and the duration of treatment ${ }^{[4]}$. Diabetic affection has been related to a higher incidence of gastrointestinal symptoms that include gastroparesis ${ }^{[6]}$ and serious small intestinal mucosal injury. Diabetic enteropathy of the large intestine manifests by diarrhea, constipation, and fecal incontinence ${ }^{[7-9]}$. Studies have shown that association of DM with chronic systemic inflammation presents a risk factor for cancer; including gastric and colorectal carcinomas ${ }^{[10-12]}$.

Cryptosporidium is an obligatory intracellular protozoan that parasitizes gastrointestinal epithelial cells. The parasites develop principally in the jejunum and ileum under the brush border of the epithelial cells $^{[13]}$. Globally, the number of reported cases of 
cryptosporidiosis is increasing, and the frequency of infection is likely to be one hundred-fold higher than the number of reported cases ${ }^{[14]}$. Parasite oocysts are transmitted primarily through the fecal oral route ${ }^{[15]}$, and hence Cryptosporidium is responsible for several waterborne outbreaks of gastrointestinal disease $\mathrm{e}^{[16-18]}$. The oocysts are highly infectious and are resistant to hard environmental conditions ${ }^{[19,20]}$. The severity, persistence, and outcome of infection depend largely on the host immune status ${ }^{[21]}$. A self-limited disease usually occurs in the immunocompetent individuals, the most common symptom being a watery diarrhoea, while in immunocompromised patients, prolonged diarrhoea can be life threatening ${ }^{[22]}$. Cryptosporidiosis pathogenesis may include increased intestinal permeability, chloride loss, altered glucose transport mechanisms in infected enterocytes, malabsorption, and host immune response to infection ${ }^{[22-24]}$. In patients with immunodeficiencies, the biliary and respiratory tracts may also be involved ${ }^{[25,26]}$. A link between cryptosporidiosis and colorectal carcinoma was suggested ${ }^{[18]}$. Cholangiocarcinoma, complicating chronic cryptosporidiosis and cholangitis, was also postulated $^{[27]}$.

Additionally, H. pylori is a gram-negative spiral bacterium, found in the stomach of about $50 \%$ of the global population. Chronicinfection mayinduce atrophic changes and metaplasia in the stomach ${ }^{[28,29]}$. Infection by $H$. pylori can spread directly from one person to the other, or indirectly through environmental exposure routes $^{[30]}$. Concomitant infection of $H$. pylori and intestinal parasites may correlate with fecal exposure. The co-colonization of the gut may be attributed to intestinal parasites affection in millions of individuals globally, thus increasing the odds of coinfection with H. pylori ${ }^{[31]}$. Besides, mutual symbiosis was postulated since $H$. pylori could provide favorable conditions for intestinal parasitosis or vice versa ${ }^{[32]}$. Results of different studies revealed that $H$. pylori infection is a risk factor for type 2-DM ${ }^{[33-35]}$. The mechanisms involved in the bacterium-type 2-DM interaction may be related to infection induced inflammation, production of inflammatory cytokines, and hormonal imbalance ${ }^{[33]}$.

The co-existence of Cryptosporidium spp. and $H$. pylori presents a challenge in diabetics. In addition to the aforementioned possible complications, both pathogens are difficult to treat with increasing reports of $H$. pylori antibiotic resistance ${ }^{[29]}$ and the lack of fully effective medication against Cryptosporidium ${ }^{[36]}$. In this context, it must be noted that detrimental consequences of DM can virtually involve all the body systems ${ }^{[37]}$, rendering diabetic patients compromised hosts. The present study was conducted to determine the burden of Cryptosporidium spp. and H. pylori among diabetic patients versus non-diabetic patients attending Kasr Al Ainy hospitals.

\section{SUBJECTS AND METHODS}

This case-control study was performed in the period from September 2018 to June 2019 on patients attending the Diagnostic and Research Unit of Parasitology (DRUP) and the Diabetes Unit, Kasr AlAiny, Faculty of Medicine, Cairo University.

Study population and sample collection: A total of 80 patients presenting with gastrointestinal symptoms and not under immunosuppressive therapy were included in the study; 40 were diabetics and 40 were non-diabetics. Patients in both groups were matched for age and sex. Relevant data were obtained from all participants comprising demographic data, gastrointestinal manifestations, and clinical history of diabetes including a significant HbA1c level. Fecal samples were collected from each patient in labeled, leak-proof, dry, and clean plastic stool containers. From each stool sample, a small part was stored at $-20^{\circ} \mathrm{C}$ for subsequent use in the coproimmunoassays, and the remaining of the sample was preserved in formalin saline fixative for parasitological examination.

Stool examination: The stool samples were examined microscopically using direct wet smear and formalinethyl acetate sedimentation methods for routine screening of ova and other parasitic stages ${ }^{[38]}$.

Coproimmunoassays: The frozen fecal specimens were thawed at room temperature before testing. For each sample, two tests were performed using RIDA QUICK Cryptosporidium ICT (R-Biopharm AG, Germany - Cat. \# N1203) for detection of Cryptosporidium coproantigens $^{[39]}$; and OnSite H. pylori Ag Rapid testCassette (CTK Biotech, Inc., San Diego, CA, USA - Cat. \# R0192C) for detection of $H$. pylori coproantigens ${ }^{[40]}$. Both tests were done according to the manufacturer's instructions.

Statistical methods: Data were coded and tabulated using the statistical package for the Social Sciences (SPSS) version 26 (IBM Corp., Armonk, NY, USA). Quantitative variables were summarized using mean, standard deviation $( \pm \mathrm{SD})$, minimum and maximum, while categorical variables were presented as frequencies (number of cases) and relative frequencies (percentages). Comparisons between groups were by unpaired t-test and chi square $\left(X^{2}\right)$ test. Exact Fisher test was used when the expected frequency was $<5$. $P$-values $<0.05$ were considered as statistically significant.

Ethical consideration: All procedures in the present work fulfilled the ethical standards recognized by Helsinki Declaration 1964. An informed consent was obtained from all participants. Infected patients were notified and prescribed the appropriate treatment. 


\section{RESULTS}

Demographic data: Of the total 80 patients included in the study, 27 (33.8\%) were males and 53 (66.2\%) females, distributed between the diabetic and nondiabetic groups (Table 1). Their ages ranged between 9 and 80 years with a mean of $46.5 \pm 15.3$ years. For the diabetic cases, the mean age was $49.7 \pm 12.9$ years, while the mean age of the non-diabetic group was $43.4 \pm 16.9$ years.

Clinical and diabetic status: Abdominal pain and diarrhea were the predominant gastrointestinal symptoms, recording $65 \%$ and $55 \%$ respectively, in the diabetic group; and $60 \%$ and $17.5 \%$ respectively, in the non-diabetic group. A significant difference in the frequency of diarrhea between both groups $(P<0.001)$ was detected. Other reported gastrointestinal manifestations including constipation, vomiting, distention, and weight loss were insignificant (Table1). Regarding the DM history, the duration of DM ranged from 0.5 to 21 years with a mean of $5.80 \pm 5.08$ years. The reported $\mathrm{HbA1c}$ level ranged from $5 \%$ to $11.2 \%$ with a mean of $6.85 \% \pm 1.95$ in the diabetic patients; of whom $27(67.5 \%)$ cases had controlled DM, while 13 $(32.5 \%)$ cases were uncontrolled.

Microscopic examination and coproimmunoassays: The rate of parasitic infections was higher in diabetic patients $(27.5 \%)$ than in non-diabetic ones (12.5\%), with no statistical significance. Direct microscopic examination of the stool samples revealed Blastocystis in $10(25 \%)$ diabetic patients $(22.2 \%$ in controlled DM versus $30.7 \%$ in uncontrolled $\mathrm{DM})$, and 2 (5\%) non- diabetic patients with statistically significant difference between them $(P<0.05)$. Detection of pathogenic $E$. histolytica complex in the non-diabetic group was insignificant (Table 1).

Using ICT test, Cryptosporidium was detected in 6 $(15 \%)$ and $2(5 \%)$ stool samples of diabetic and nondiabetic groups, respectively, with no statistically significant difference (Table 1). Co-infection of Cryptosporidium and Blastocystis as detected by coproimmunoassay and fecal microscopic examination respectively, was observed in the diabetic group with statistically significant association $(P<0.05)$ (Table 2$)$. Among the diabetic patients, there was a statistically significant $(P<0.05)$ association between diarrhea and Cryptosporidium infection rate. No statistically significant association was observed between Cryptosporidium positivity and diabetic patients' age or sex (Figure 1 and Table 2).

Regarding H. pylori infection rate, the immunoassay test was positive in $24(60 \%)$ patients in each of the diabetic and non-diabetic groups (Table 1). A significant difference $(P<0.05)$ was found in the mean age between $H$. pylori positive and negative cases in the diabetic group (Figure 1). Chi-square test showed no significant association of $H$. pylori positivity in the diabetic cases with sex and clinical symptoms (Table 3 ). In the diabetic group, co-infection of Cryptosporidium and H. pylori was detected in 4 out of 6 Cryptosporidium positive cases $(3.7 \%$ in controlled DM versus $23.1 \%$ in uncontrolled DM) (Table 4), without significant association; 3 out of 4 of co-infected cases also had Blastocystis.

Table 1. Demographic, clinical and infection characteristics in the study population.

\begin{tabular}{|c|c|c|c|c|}
\hline \multirow{2}{*}{\multicolumn{2}{|c|}{$\begin{array}{l}\text { Demographic, clinical and } \\
\text { infection characteristics }\end{array}$}} & Diabetic $($ No. $=40)$ & Non-diabetic $($ No. $=40)$ & \multirow{2}{*}{$\begin{array}{c}\text { Statistical analysis } \\
(P \text { value })\end{array}$} \\
\hline & & No. (\%) & No. (\%) & \\
\hline \multirow[t]{2}{*}{ Sex } & Male & $10(25.0 \%)$ & $17(42.5 \%)$ & \multirow{2}{*}{0.098} \\
\hline & Female & $30(75.0 \%)$ & $23(57.5 \%)$ & \\
\hline Age & Mean \pm SD & $49.7 \pm 12.9$ & $43.4 \pm 16.9$ & 0.062 \\
\hline \multicolumn{5}{|c|}{ Clinical } \\
\hline \multicolumn{2}{|c|}{ Diarrhea } & $22(55.0 \%)$ & $7(17.5 \%)$ & $<0.001^{*}$ \\
\hline \multicolumn{2}{|c|}{ Abdominal pain } & $26(65.0 \%)$ & $24(60 \%)$ & 0.644 \\
\hline \multicolumn{2}{|c|}{ Constipation } & $6(15.0 \%)$ & $1(2.5 \%)$ & 0.108 \\
\hline \multicolumn{2}{|c|}{ Distension } & $6(15.0 \%)$ & $1(2.5 \%)$ & 0.108 \\
\hline \multicolumn{2}{|c|}{ Weight loss } & $1(2.5 .0 \%)$ & $1(2.5 \%)$ & 1 \\
\hline \multicolumn{2}{|c|}{ Vomiting } & $1(2.5 \%)$ & $3(7.5 \%)$ & 0.615 \\
\hline \multirow[t]{2}{*}{ DM } & Controlled ${ }^{@}$ & $27(67.5 \%)$ & - & - \\
\hline & Uncontrolled $^{\#}$ & $13(32.5 \%)$ & - & - \\
\hline \multicolumn{5}{|c|}{ Infection } \\
\hline \multicolumn{2}{|c|}{ Parasites } & $11(27.5)$ & $5(12.5 \%)$ & 0.093 \\
\hline \multicolumn{2}{|c|}{ Blastocystis spp. } & $10(25.0 \%)$ & $2(5.0 \%)$ & $0.012^{*}$ \\
\hline \multicolumn{2}{|c|}{ E. histolytica/E. dispar } & $0(0.0 \%)$ & $1(2.5 \%)$ & 1 \\
\hline \multicolumn{2}{|c|}{ Cryptosporidium spp. } & $6(15.0 \%)$ & $2(5.0 \%)$ & 0.263 \\
\hline \multicolumn{2}{|c|}{ H. pylori } & $24(60.0 \%)$ & $24(60.0 \%)$ & 1 \\
\hline \multicolumn{2}{|c|}{ Total of infections } & $28(70 \%)$ & $26(65 \%)$ & 0.633 \\
\hline
\end{tabular}


PARASITOLOGISTS UNITED JOURNAL

Table 2. Association between cryptosporidiosis and demographic, clinical and infection characteristics in the diabetic patients.

\begin{tabular}{|c|c|c|c|c|}
\hline \multirow{2}{*}{\multicolumn{2}{|c|}{$\begin{array}{l}\text { Demographic, clinical and } \\
\text { infection characteristics }\end{array}$}} & \multicolumn{2}{|c|}{ Cryptosporidium spp. } & \multirow{3}{*}{$\begin{array}{c}\begin{array}{c}\text { Statistical analysis } \\
(\boldsymbol{P} \text { value) }\end{array} \\
1\end{array}$} \\
\hline & & \multirow{2}{*}{$\begin{array}{c}\begin{array}{c}\text { Positive (No. = 6) } \\
\text { No. (\%) }\end{array} \\
1(10 \%) \\
5(16.7 \%) \\
\end{array}$} & \multirow{2}{*}{$\begin{array}{c}\text { Negative (No. = 34) } \\
\text { No. (\%) }\end{array}$} & \\
\hline Sex & $\begin{array}{l}\text { Male } \\
\text { Female }\end{array}$ & & & \\
\hline Age & Mean $\pm S D$ & $48.83 \pm 19.32$ & $49.88 \pm 11.85$ & 0.857 \\
\hline Diarrhea & $\begin{array}{l}\text { Positive } \\
\text { Negative }\end{array}$ & $\begin{array}{c}6(27.3 \%) \\
0(0.0 \%)\end{array}$ & $\begin{array}{l}16(72.7 \%) \\
18(100 \%)\end{array}$ & $0.024^{*}$ \\
\hline Abdominal pain & $\begin{array}{l}\text { Positive } \\
\text { Negative }\end{array}$ & $\begin{array}{l}4(15.4 \%) \\
2(14.3 \%)\end{array}$ & $\begin{array}{l}22(84.6 \%) \\
12(85.7 \%)\end{array}$ & 1 \\
\hline Constipation & $\begin{array}{l}\text { Positive } \\
\text { Negative }\end{array}$ & $\begin{array}{l}0(0.0 \%) \\
6(100 \%)\end{array}$ & $\begin{array}{c}6(100 \%) \\
28(82.4 \%)\end{array}$ & 0.565 \\
\hline Distension & $\begin{array}{l}\text { Positive } \\
\text { Negative }\end{array}$ & $\begin{array}{l}0(0.0 \%) \\
6(17.6 \%)\end{array}$ & $\begin{array}{c}6(100 \%) \\
28(82.4 \%)\end{array}$ & 0.565 \\
\hline Weight loss & $\begin{array}{l}\text { Positive } \\
\text { Negative }\end{array}$ & $\begin{array}{l}1(100 \%) \\
5(12.8 \%)\end{array}$ & $\begin{array}{c}0(0.0 \%) \\
34(87.2 \%)\end{array}$ & 0.150 \\
\hline Vomiting & $\begin{array}{l}\text { Positive } \\
\text { Negative }\end{array}$ & $\begin{array}{c}0(0.0 \%) \\
6(15.4 \%)\end{array}$ & $\begin{array}{c}1(100 \%) \\
33(84.6 \%)\end{array}$ & 1 \\
\hline Blastocystis spp. & $\begin{array}{l}\text { Positive } \\
\text { Negative }\end{array}$ & $\begin{array}{l}5(83.3 \%) \\
1(16.7 \%)\end{array}$ & $\begin{array}{c}5(14.7 \%) \\
29(85.3 \%) \\
\end{array}$ & $0.002^{*}$ \\
\hline H. pylori & $\begin{array}{l}\text { Positive } \\
\text { Negative }\end{array}$ & $\begin{array}{l}4(66.7 \%) \\
2(33.3 \%)\end{array}$ & $\begin{array}{l}20(58.8 \%) \\
14(41.2 \%)\end{array}$ & 1 \\
\hline
\end{tabular}

*: Statistically significant $(P<0.05)$.

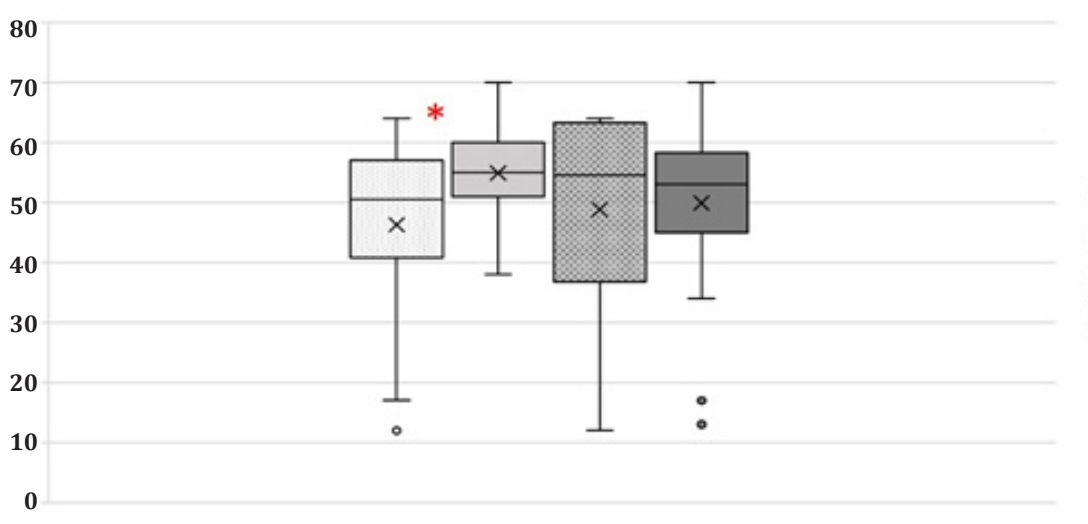

Fig. 1. Age distribution of diabetic cases in relation $\square$ H. pylori + to positive and negative $H$. $\square$ H. pylori 圆Cryptosporidium + pylori and Cryptosporidium infection.

*: Statistically significant difference $\quad(P<0.05) \quad$ in the mean age between $H$. pylori positive and negative cases.

Table 3. Association between H. pylori positivity and demographic and clinical characteristics in the diabetic patients.

\begin{tabular}{|c|c|c|c|c|}
\hline \multirow{2}{*}{\multicolumn{2}{|c|}{$\begin{array}{l}\text { Demographic, clinical and } \\
\text { infection characteristics }\end{array}$}} & \multicolumn{2}{|c|}{ H. pylori } & \multirow{3}{*}{$\begin{array}{c}\begin{array}{c}\text { Statistical analysis } \\
(\boldsymbol{P} \text { value })\end{array} \\
0.159\end{array}$} \\
\hline & & \multirow{2}{*}{$\begin{array}{c}\text { Positive (No.= 24) } \\
\text { No. (\%) }\end{array}$} & \multirow{2}{*}{$\begin{array}{c}\begin{array}{c}\text { Negative (No. = 16) } \\
\text { No. (\%) }\end{array} \\
6(60 \%) \\
10(33.3 \%) \\
\end{array}$} & \\
\hline Sex & $\begin{array}{l}\text { Male } \\
\text { Female }\end{array}$ & & & \\
\hline Age & Mean \pm SD & $46.29 \pm 14.76$ & $54.88 \pm 7.26$ & $0.020^{*}$ \\
\hline Diarrhea & $\begin{array}{l}\text { Positive } \\
\text { Negative }\end{array}$ & $\begin{array}{l}14(63.6 \%) \\
10(55.6 \%) \\
\end{array}$ & $\begin{array}{l}8(36.4 \%) \\
8(44.4 \%) \\
\end{array}$ & 0.604 \\
\hline Abdominal pain & $\begin{array}{l}\text { Positive } \\
\text { Negative }\end{array}$ & $\begin{array}{l}13(50.0 \%) \\
11(78.6 \%)\end{array}$ & $\begin{array}{l}13(50.0 \%) \\
3(21.4 \%)\end{array}$ & 0.079 \\
\hline Constipation & $\begin{array}{l}\text { Positive } \\
\text { Negative }\end{array}$ & $\begin{array}{l}4(66.7 \%) \\
20(58.8 \%) \\
\end{array}$ & $\begin{array}{l}2(33.3 \%) \\
14(41.2 \%) \\
\end{array}$ & 1 \\
\hline Distension & $\begin{array}{l}\text { Positive } \\
\text { Negative }\end{array}$ & $\begin{array}{l}4(66.7 \%) \\
20(58.8 \%) \\
\end{array}$ & $\begin{array}{l}2(33.3 \%) \\
14(41.2 \%) \\
\end{array}$ & 1 \\
\hline Weight loss & $\begin{array}{l}\text { Positive } \\
\text { Negative }\end{array}$ & $\begin{array}{c}1(100 \%) \\
23(59.0 \%)\end{array}$ & $\begin{array}{c}0(0.0 \%) \\
16(41.0 \%)\end{array}$ & 1 \\
\hline Vomiting & $\begin{array}{l}\text { Positive } \\
\text { Negative }\end{array}$ & $\begin{aligned} 0 & (0.0 \%) \\
24 & (61.5 \%)\end{aligned}$ & $\begin{array}{c}1(100 \%) \\
15(38.5 \%)\end{array}$ & 0.400 \\
\hline Cryptosporidium spp. & $\begin{array}{l}\text { Positive } \\
\text { Negative }\end{array}$ & $\begin{array}{l}4(66.7 \%) \\
20(58.8 \%)\end{array}$ & $\begin{array}{l}2(33.3 \%) \\
14(41.2 \%)\end{array}$ & 1 \\
\hline
\end{tabular}


Table 4. Cryptosporidium spp. and H. pylori infections in diabetic and non-diabetic participants as diagnosed by copro-immunoassays.

\begin{tabular}{|c|c|c|c|c|c|c|}
\hline & & \multicolumn{4}{|c|}{ DM } & \multirow{4}{*}{$\begin{array}{c}\text { Statistical } \\
\text { analysis } \\
(P \text { value })\end{array}$} \\
\hline & & \multicolumn{3}{|c|}{ Positive } & \multirow{2}{*}{$\begin{array}{l}\text { Negative } \\
(\text { No. }=40)\end{array}$} & \\
\hline & & $\begin{array}{c}\text { Total } \\
(\text { No. }=40)\end{array}$ & $\begin{array}{c}\text { Controlled }^{@} \\
\text { (No.= 27) }\end{array}$ & $\begin{array}{l}\text { Uncontrolled }^{\#} \\
\text { (No. = 13) }\end{array}$ & & \\
\hline & & No. (\%) & No. (\%) & No. $(\%)$ & No. (\%) & \\
\hline Cryptosporidium spp. & $\begin{array}{l}\text { Positive } \\
\text { Negative }\end{array}$ & $\begin{array}{c}6(15.0) \\
34(85.0)\end{array}$ & $\begin{array}{c}2(7.4) \\
25(92.6)\end{array}$ & $\begin{array}{l}4(30.8) \\
9(69.2)\end{array}$ & $\begin{array}{c}2(5.0) \\
38(95.0)\end{array}$ & 0.075 \\
\hline H. pylori & $\begin{array}{l}\text { Positive } \\
\text { Negative }\end{array}$ & $\begin{array}{l}24(60.0) \\
16(40.0)\end{array}$ & $\begin{array}{l}14(51.9) \\
13(48.1)\end{array}$ & $\begin{array}{c}10(76.9) \\
3(23.1)\end{array}$ & $\begin{array}{l}24(60.0) \\
16(40.0)\end{array}$ & 0.13 \\
\hline Co-infection & $\begin{array}{l}\text { Positive } \\
\text { Negative }\end{array}$ & $\begin{array}{c}4(10.0) \\
36(90.0)\end{array}$ & $\begin{array}{c}1(3.7) \\
26(96.3)\end{array}$ & $\begin{array}{c}3(23.1) \\
23(76.9)\end{array}$ & $\begin{array}{c}2(5.0) \\
38(95.0)\end{array}$ & 0.09 \\
\hline
\end{tabular}

@: HbA1c <7\%; \#: HbA1c > 7\%.

\section{DISCUSSION}

Impairment of the immune system of diabetics together with the existing metabolic imbalance, may increase the susceptibility to pathogenic agents. A limited number of epidemiological studies haveinquired into the association of DM and parasitic infections. Chronic parasitic infections can have an impact on DM risk and enteropathy through converted immune regulation, malnutrition, diarrhea, and gut microbiome alteration ${ }^{[41]}$. Cryptosporidium and $H$. pylori infections can be associated with significant morbidity exerting extra burden on the already stressed diabetic patients. In the present study, using ICT, Cryptosporidium spp. infection was detected in $15 \%$ of diabetics; with a frequency of $7.4 \%$ in patients with controlled DM versus $30.8 \%$ in patients with uncontrolled DM, and in $5 \%$ of non-diabetics with no significant difference. However, Cryptosporidium infection in the diabetic patients showed no significant relation with age, sex, or glycemic control, but had a significant association with diarrhea. Using microscopy, Blastocystis was the most frequently detected parasite, with significantly higher rate in diabetics (25\%) than in non-diabetics (5\%). In a study at Sohag University Hospital, Cryptosporidium spp. was detected in 5\% of diabetic patients by MZN staining. The most frequent parasite was G. lamblia (22\%), followed by E. histolytica $(7 \%)^{[42]}$. Mohtashamipour et al. ${ }^{[43]}$ revealed a Cryptosporidium infection rate of $1.6 \%$ in stained Kinyoun acid-fast samples in a case-control study on diabetics attending Endocrine and Metabolism Research Centre, Isfahan/ Iran. The most reported infections were Blastocystis (9.3\%), Endolimax nana (5.1\%) and G. lamblia (3.4\%). Tangi et al. $^{[44]}$ in a similar study on intestinal parasites in DM patients in Limbe and Buca Municipalities, Cameroon, estimated a prevalence of Cryptosporidium of $0.67 \%$ by MZN, whereas the most frequent parasite was E. histolytica (6.7\%) followed by Blastocystis $(2.7 \%)$.

However, Alemu et al. ${ }^{[45]}$ found that among diabetics at Arba Minch Hospital, Ethiopia, Cryptosporidium had the highest frequency (8.4\%), then Ascaris (3.7\%) and G. lamblia (2.8\%). Waly et al. ${ }^{[46]}$ revealed a prevalence of $44 \%$ for intestinal parasites among diabetic patients attending Beni-Suef University Hospital, Egypt. The prevailing parasites were Blastocystis (29\%), Cryptosporidium spp. (12\%), G. lamblia (7\%), and Microsporidium spp. (5\%).

In our study, infection with H. pylori was detected at a rate of $60 \%$ in diabetic cases, $51.9 \%$ with controlled DM versus $76.9 \%$ with uncontrolled DM, as well as in $60 \%$ of non-diabetic patients. Unlike Cryptosporidium the only significant relation of $H$. pylori positivity was with the mean age of diabetics $(P<0.05)$ and not with any of the other parameters. As in DM, H. pylori infections are associated with gastrointestinal inflammation that interferes with absorption of glucose and lipids ${ }^{[4]}$. In hospital based cross sectional studies, H. pylori infection was positive in $73 \%$ of diabetics versus $51.4 \%$ in the non-diabetic group at Liaquat University Hospital/ Pakistan $^{[48]}$; and $73.11 \%$ and $58.05 \%$ in diabetics and non-diabetics respectively in Douala, Cameroon ${ }^{[34]}$.

Concurrent infection of $H$. pylori and intestinal parasites was reported in a number of studies ${ }^{[31,32,49-53]}$. Under normal conditions, gastric juice creates an unfavorable medium for pathogenic microorganisms. H. pylori infection causes alteration in gastric acid secretion, moreover the bacterium can compromise the gastric mucosal barrier, depending on the site and duration of the infection; thus allowing a favorable medium for intestinal parasitosis ${ }^{[54,55]}$. Ghallab and Morsy ${ }^{[56]}$ observed that $H$. pylori was highly prevalent in gastrointestinal symptomatic patients attending Kafrelsheikh University Hospital, and that Blastocystis (68\%), Cryptosporidium spp. (32\%), G. lamblia (31\%) and E. histolytica complex (27\%) were more frequent in $H$. pylori infected patients.

It is worth noting that polymicrobial interactions in the complex intestinal niche can tremendously influence the course of a disease ${ }^{[57]}$. In fact the concomitant presence of intestinal protozoa and $H$. pylori can result 
in an amplified $\mathrm{T}$ helper (Th1) response which fails to clear the infection and exaggerates the mucosal damage ${ }^{[58]}$. Few studies investigated the dual infection of Cryptosporidium and H. pylori in diabetic patients ${ }^{[41]}$. In the present study, coinfection of Cryptosporidium and $H$. pylori was demonstrated in $4(10 \%)$ diabetic patients with no statistical significance, but of which 3 patients also had Blastocystis infection.

Rady and colleagues ${ }^{[59]}$ investigated the occurrence of intestinal parasites and H. pylori infection among diabetic children attending Aboul-Reesh University Hospital, Egypt. The authors reported an infection rate of $45.26 \%$ in diabetics, versus $20 \%$ in nondiabetics, for intestinal parasites; and a $39.47 \%$ infection rate versus $42.3 \%$ rate in non-diabetics, for H. pylori. Cryptosporidium was prevalent in $9.2 \%$ of diabetics compared to $0.84 \%$ in non-diabetics with statistically significant difference. $H$. pylori positivity was significantly associated with $G$. lamblia infection (10.56\%), whereas association with Cryptosporidium (5.59\%) and Blastocystis (9.32\%) were non-significant.

In conclusion, our results revealed a higher infection rate of Cryptosporidium among diabetic patients in comparison to non-diabetics, while $H$. pylori infection was evenly detected in both groups. Co-infection with Cryptosporidium and $H$. pylori occurred in $10 \%$ of diabetic cases, yet its clinical significance needs further investigations. Blastocystis was the most frequently detected parasite, showing a significantly higher rate in diabetics. Being stressed hosts, especially in poorly controlled glycemic state, diabetic patients need screening for intestinal parasites to control the infections, reduce morbidity and risk of complications.

Author contribution: All authors have substantially contributed to research design, data collection and processing, analysis, and interpretation of results, writing and editing the manuscript.

Conflict of interest: The authors declare that there is no conflict of interest.

Funding statement: No funding sources.

\section{REFERENCES}

1. Cho NH, Shaw JE, Karuranga S, Huang Y, Da Rocha Fernandes JD, Ohlrogge AW, et al. IDF Diabetes Atlas: Global estimates of diabetes prevalence for 2017 and projections for 2045. Diabetes Res Clin Pract 2018; 138: 271-281.

2. Hegazi R, El-Gamal M, Abdel-Hady N, Hamdy 0 . Epidemiology of and risk factors for type 2 diabetes in Egypt. Ann Glob Health 2015; 81(6):814-820.

3. American Diabetes Association. Standards of medical care in diabetes-2018. Diabetes Care 2018; 4:S1-S159.

4. Berbudi A, Rahmadika N, Tjahjadi AI, Ruslami R. Type 2 diabetes and its impact on the immune system. Curr Diabetes Rev 2020; 16(5):442-449.
5. Daryabor G, Atashzar MR, Kabelitz D, Meri S, Kalantar $\mathrm{K}$. The effects of type 2 diabetes mellitus on organ metabolism and the immune system. Front Immunol 2020; $11: 1582$.

6. Krishnasamy S, Abell T. Diabetic gastroparesis: principles and current trends in management. Diabetes Ther 2018; 9 (Suppl 1):1-42.

7. Bytzer P, Talley NJ, Hammer J, Young LJ, Jones MP, Horowitz M. GI symptoms in diabetes mellitus are associated with both poor glycemic control and diabetic complications. Am J Gastroenterol 2002; 97(3):604-611.

8. D'Addio F, La Rosa S, Maestroni A, Jung P, Orsenigo E, Ben Nasr M, et al. Circulating IGF-I and IGFBP3 levels control human colonic stem cell function and are disrupted in diabetic enteropathy. Cell Stem Cell 2015; 17(4):486-498.

9. Zhong HJ, Yuan Y, Xie WR, Chen MH, He XX. Type 2 diabetes mellitus is associated with more serious small intestinal mucosal injuries. PLoS One 2016; 11(9):e0162354.

10. Ma Y, Yang W, Song M, Smith-Warner SA, Yang J, Li Y, et al. Type 2 diabetes and risk of colorectal cancer in two large U.S. prospective cohorts. Br J Cancer 2018; 119(11):1436-1442.

11. Cheung KS, Chan EW, Chen L, Seto WK, Wong ICK, Leung WK. Diabetes increases risk of gastric cancer after Helicobacter pylori eradication: a territory-wide study with propensity score analysis. Diabetes Care 2019; 42(9):1769-1775.

12. Yang HJ, Kang D, Chang Y, Ahn J, Ryu S, Cho J, et al. Diabetes mellitus is associated with an increased risk of gastric cancer: a cohort study. Gastric Cancer 2020; 23(3):382390.

13. Leitch GJ, He Q. Cryptosporidiosis: An overview. J Biomed Res 2012; 25(1):1-16.

14. Shrivastava AK, Kumar S, Smith WA, Sahu PS. Revisiting the global problem of cryptosporidiosis and recommendations. Trop Parasitol 2017; 7(1):8-17.

15. Tzipori S, Ward H. Cryptosporidiosis: biology, pathogenesis and disease. Microbes Infect 2002; 4(10):1047-1058.

16. Baldursson S, Karanis P. Waterborne transmission of protozoan parasites: review of worldwide outbreaks - an update 2004-2010. Water Res 2011; 4(20):6603-6614.

17. Efstratiou A, Ongerth J, Karanis P. Waterborne transmission of protozoan parasites: review of worldwide outbreaks: An update 2011-2016. Water Res 2017; 114:14-22.

18. Sawant M, Baydoun M, Creusy C, Chabe M, Viscogliosi E, Certad G, et al. Cryptosporidium and colon cancer: cause or consequence? Microorganisms 2020; 8(11):1665.

19. Okhuysen PC, Chappell CL, Crabb JH, Sterling CR, DuPont HL. Virulence of three distinct Cryptosporidium parvum isolates for healthy adults. J Infect Dis 1999;180 (4):12751281.

20. Chappell CL, Okhuysen PC, Langer-Curry R, Widmer G, Akiyoshi DE, Tanriverdi S, et al. Cryptosporidium hominis: experimental challenge of healthy adults. Am J Trop Med Hyg 2006; 75(5):851-857.

21. Petry F, Jakobi V, Tessema TS. Host immune response to Cryptosporidium parvum infection. Exp Parasitol 2010; 126(3):304-309. 
22. Gerace E, Lo Presti VDM, Biondo C. Cryptosporidium infection: epidemiology, pathogenesis, and differential diagnosis. Eur J Microbiol Immunol 2019; 9(4):119-123.

23. Garza A, Lackner A, Aye P, D’Souza M, Martin Jr P, Borda J, et al. Substance $\mathrm{P}$ receptor antagonist reverses intestinal pathophysiological alterations occurring in a novel ex-vivo model of Cryptosporidium parvum infection of intestinal tissues derived from SIV-infected macaques. J Med Primatol 2008; 37 (3): 109-115.

24. Delling C, Daugschies A, Bangoura B, Dengler F. Cryptosporidium parvum alters glucose transport mechanisms in infected enterocytes. Parasitol Res 2019; 118(12):3429-3441.

25. Montero JA, Sinnott J, Holt DA, Lloyd C. Biliary cryptosporidiosis: current concepts. Infect Med 2001; 18(6):312-316.

26. Sponseller JK, Griffiths JK, Tzipori S. The evolution of respiratory cryptosporidiosis: evidence for transmission by inhalation. Clin Microbiol Rev 2014; 27(3):575-586.

27. Rahman M, Chapel H, Chapman RW, Collier JD. Cholangiocarcinoma complicating secondary sclerosing cholangitis from cryptosporidiosis in an adult patient with CD40 ligand deficiency: case report and review of the literature. Int Arch Allergy Immunol 2012; 159(2):204208.

28. Sugano K, Tack J, Kuipers EJ, Graham DY, El-Omar EM, Miura S et al. Kyoto global consensus report on Helicobacter pylori gastritis. Gut 2015; 64(9):1353-1367.

29. Wang D, Guo Q, Yuan Y, Gong Y. The antibiotic resistance of Helicobacter pylori to five antibiotics and influencing factors in an area of China with a high risk of gastric cancer. BMC Microbiol 2019; 19:152.

30. Mladenova I, Durazzo M. Transmission of Helicobacter pylori. Minerva Gastroenterol Dietol 2018; 64(3):251-254.

31. Pomari E, Ursini T, Silva R, Leonardi M, Ligozzi M, Angheben A. Concomitant infection of Helicobacter pylori and intestinal parasites in adults attending a referral centre for parasitic infections in north eastern Italy. J Clin Med 2020; 9(8): 2366.

32. Ibrahim A, Ali YBM, Abdel-Aziz A, El-Badry AA. Helicobacter pylori and enteric parasites co-infection among diarrheic and non-diarrheic Egyptian children: seasonality, estimated risks, and predictive factors. J Parasit Dis 2019; 43(2):198-208.

33. Nodoushan SAH, Nabavi A. The interaction of Helicobacter pylori infection and type 2 diabetes mellitus. Adv Biomed Res 2019; 8:15.

34. Kouitcheu Mabeku LB, Noundjeu Ngamga ML, Leundji H. Helicobacter pylori infection, a risk factor for type 2 diabetes mellitus: a hospital-based cross-sectional study among dyspeptic patients in Douala-Cameroon. Sci Rep 2020; 10(1):12141.

35. Mansori K, Moradi Y, Naderpour S, Rashti R, Moghaddam $\mathrm{AB}$, Saed L, et al. Helicobacter pylori infection as a risk factor for diabetes: a meta-analysis of case-control studies. BMC Gastroenterol 2020; 20(1):77.

36. Hasan MM, Stebbins EE, Choy RKM, Gillespie JR, De Hostos EL, Miller P, et al. Spontaneous selection of Cryptosporidium drug resistance in a calf model of infection. Antimicrob Agents Chemother 2021; 65(6):e00023-21.
37. Krishnan B, Babu S, Walker J, Walker AB, Pappachan JM. Gastrointestinal complications of diabetes mellitus. World J Diabetes 2013; 4(3):51-63.

38. Garcia LS. Diagnostic Medical Parasitology, $5^{\text {th }}$ ed. 2007; ASM Press, Washington, D.C.

39. Elbeshti LM, Shawesh F, Elazomi A, Hamat RA. Prevalence of intestinal cryptosporidiosis in Malaysian children with malignancies. Int J New Technol Res 2019; 5(9):14-26.

40. Demerdash DME, Ibrahim H, Hassan DM, Moustafa H, Tawfik NM. Helicobacter pylori associated to unexplained or refractory iron deficiency anemia: an Egyptian singlecenter experience. Hematol Transfus Cell Ther 2018; 40(3):219-225.

41. Htun NSN, Odermatt P, Müller I, Yap P, Steinmann P, Schindler $\mathrm{C}$, et al. Association between gastrointestinal tract infections and glycated hemoglobin in school children of poor neighborhoods in Port Elizabeth, South Africa. PLoS Negl Trop Dis 2018; 12(3):e0006332.

42. Elnadi NA, Hassanien HA, Ahmad AM, Abd-Ellah AK. Intestinal parasites in diabetic patients in Sohag university hospitals, Egypt. J Egypt Soc Parasitol 2015; 45(2):443-449.

43. Mohtashamipour M, Ghaffari-Hoseini SG, Pestehchian $\mathrm{N}$, Yousefi H, Fallah E, Hazratian T. Intestinal parasitic infections in patients with diabetes mellitus: A casecontrol study. J Anal Res Clin Med 2015; 3(3):157-163.

44. Tangi FB, Fokam EB, Longdoh NA, Eteneneng EJ. Intestinal parasites in diabetes mellitus patients in the Limbe and Buea municipalities, Cameroon. Diabetes Res Open J 2016; 2(1):1-7.

45. Alemu G, Jemal A, Zerdo Z. Intestinal parasitosis and associated factors among diabetic patients attending Arba Minch Hospital, Southern Ethiopia. BMC Res Notes 2018; 11(1) 689.

46. Waly WR, Ismail MA, Abu-Sarea EY, Abd El Wahab WM. Intestinal parasitic infections and associated risk factors in diabetic patients: a case-control study. J Parasit Dis 2021; DOI: 10.1007/s12639-021-01402-0.

47. He C, Yang Z, Lu NH. Helicobacter pylori infection and diabetes: is it a myth or fact? World J Gastroenterol 2014; 20(16):4607-4617.

48. Devrajani BR, Shah SZA, Soomro AA, Devrajani T. Type 2 diabetes mellitus: a risk factor for Helicobacter pylori infection: a hospital based case-control study. Int J Diabetes Dev Ctries 2010; 30(1):22-26.

49. Fadul N, Ahmed M, Elamin T, Elfaki M, Elsayid M. Prevalence rate of Giardia lamblia, Helicobacter pylori coinfections in Khartoum state Sudan, Int J Sci Technol Res 2016; 5(3):181-190.

50. Kazemian H, Heidari H, Yamchi JK, Shavalipour A, Ghafourian S, Mohebi R, et al. Relationship between Helicobacter pylori infection and parasitic infection in patients in Ilam, Infect Epidemiol Med 2016; 2(2):15-17.

51. El-Badry A, Ghieth M, Ahmed D, Ismail M. Giardia intestinalis and Helicobacter pylori co-infection: Estimated risks and predictive factors in Egypt. J Egypt Soc Parasitol 2017; 47(1):19-24.

52. Seid A, Tamir Z, Kasanew B, Senbetay M. Co-infection of intestinal parasites and Helicobacter pylori among upper gastrointestinal symptomatic adult patients attending 
Mekanesalem hospital, northeast Ethiopia. BMC Res Notes 2018; $11: 144$.

53. Spotts H, Walelign S, Tesfaye M, Desta K, Tsegaye A, Taye B. Concurrent infection of intestinal parasites and Helicobacter pylori among school-age children in central Ethiopia. Parasite Epidemiol Control 2020; 11:e00177.

54. Wroblewski LE, Peek RM, Wilson KT. Helicobacter pylori and gastric cancer: factors that modulate disease risk. Clin Microbiol Rev 2010; 23(4):713-739.

55. Waldum HL, Kleveland PM, Sørdal ØF. Helicobacter pylori and gastric acid: an intimate and reciprocal relationship. Therap Adv Gastroenterol 2016; 9(6):836-844.

56. Ghallab MMI, Morsy SM. Helicobacter pylori co-infected with common intestinal protozoa in gastrointestinal symptomatic patients. J Egypt Soc Parasitol 2020 50(2):390-393.

57. Frisan T. Co- and polymicrobial infections in the gut mucosa: the host-microbiota-pathogen perspective. Cell Microbiol 2021; 23(2):e13279.

58. Hussain Z, El-Omar E, Lee YY. Dual infective burden of Helicobacter pylori and intestinal parasites: good or bad news for the host? Indian J Gastroenterol 2020; 39(2):111-116.

59. Rady HI, Elkazazz A, El Saftawy EA, Abdelrazek NM. Parasites and Helicobacter pylori in Egyptian children with or without diabetes with gastrointestinal manifestations and high calprotectin level. J Egypt Soc Parasitol 2019; 49(1):243-248. 